\title{
Pesticide Usage Pattern: In Peanut Grown Area of Junagadh
}

\author{
G.R. Hithesh ${ }^{1} *$ and G. Harish ${ }^{2}$ \\ ${ }^{1}$ Entomology Junagadh Agricultural University, Junagadh-362001, India \\ ${ }^{2}$ Directorate of Groundnut Research, Junagadh-362001, India \\ *Corresponding author
}

\begin{abstract}
Keywords
Imidacloprid,

Pesticides,

Hexaconazole,

Targa super

Article Info

Accepted:

07 November 2018

Available Online:

10 December 2018 insecticides viz, Fipronil, Cypermethrin, Diafenthiuron, Novaluron, Buprofezin, Spinosad were not sold in Junagadh market and three new insecticide options were available for pest control in groundnut they were profenocyper, phosphomidon, lambdacyhalothrin. This trend helps us to say that most of the chemical sold had systemic action and used as seed treatment chemicals. Recent outbreak of white grubs and lepidopteran pests has resulted in such trend where Imidacloprid and Coragen were used by farmers for management of these pests. Similarly 13 fungicides were available in market for disease management among them Hexaconazole was the popularly sold product during both the years followed by Tebuconazole, Carbendazim, Difenconazole. In 2017-18 fungicide Hexaconazole was sold more in market to control of groundnut diseases. Among herbicides 11 were available in market for weed management among them Targa super was the popular sold product during both the years followed by Sodium Aciflurofen+Clodinafoppropargyl, Glyphosate. Targa super is effective in control of narrow leaf weeds. Hence we can conclude that incidence of insect pests, diseases and weeds in groundnut has resulted in the dynamics of pesticide usage in the local market.
\end{abstract}

\section{A B S T R A C T}

A survey was conducted in Junagadh district to know the pesticide usage pattern in groundnut during Kharif 2016-17 and 2017-18. Results showed that around 20 insecticides were available in market for pest management among them Imidicloprid was the popularly sold product during both the years followed by thiamethoxam and Coragen. In 2017-18 six

\section{Introduction}

Groundnut (Arachis hypogaea L.) is important food legume and oilseed crop. The total area of groundnut cultivation in India is 52.50 lakh ha which accounts for total production of 94.72 lakh tones with productivity of 1804 $\mathrm{kg} / \mathrm{ha}$. Among the major groundnut growing states, Gujarat is the most important one accounting for 18.42 lakh ha total area with
49.18 lakh tones production and productivity of $2670 \mathrm{~kg} / \mathrm{ha}$ (Anon, 2016). The productivity level of groundnut in India is far below the world average of $1400 \mathrm{~kg} / \mathrm{ha}$ mainly because it is predominantly grown as a rain fed crop ( $80 \%$ of the total acreage) under various biotic and abiotic constraints that limit crop yield. Due to these biotic factors, there is drastically reduction in yield. The major pests of groundnut are White grub, Holotrichia 
consanguinea, Red hairy caterpillar, Amsacta albistriga, Leaf miner, Aproaerema modicella and sucking pests like aphids, thrips and leaf hopper. The major diseases of groundnut are Alternaria leaf disease, Stem rot and Bud necrosis transmitted by Thrips. Weeds are potential competitors with crops for nutrients, moisture, light and space. Control of weeds particularly in cropping system is vitally important to check the loss caused by them. Yield loss due to weed infestation amounts to 80 per cent in groundnut (Murthy et al., 1994). Hence, the Pesticides constitutes the key control strategy for crop pests and disease management and have been making significant contribution towards improving the crop yields. In recent years, the use of pesticides has become widespread practice for preventing, controlling and destroying pests. According to Central Insecticide Board \& Registration Committee (CIB\&RC), the major insecticides such as Carbofuran, Deltamethrin, Imidacloprid, Phorate, Quinalphos and Thiamethoxam are used for controlling pests. The major fungicides such as Carbendazim, Mancozeb, Metiram, Propiconazole, Pyraclostrobin, Sulphur, Tebuconazole, Thiram used for controlling diseases.

The major herbicides such as Alachlor, Imazethapyr, Quizalofop ethyl, Fluazifop-pbutyl + Fomesfen used for controlling weeds. Many pesticides are available in market for management of pests, diseases and weeds of groundnut and also with emergence or outbreak of new species the trend of pesticides changes. Hence a survey was carried out to know the pesticide usage pattern in groundnut.

\section{Materials and Methods}

A survey was carried out in Junagadh district local pesticide market during two years Kharif 2016-17 and 2017-18. In Junagadh district, more than 100 pesticide shops were present out of which a simple random survey was conducted in local market with sample size of 50 shops. The pesticides sold in market during two years were recorded. The observations on amount of different pesticides sold in the market during two years for controlling of pests, diseases and weeds in groundnut were recorded. The data was analyzed statistically and ranking was given on the number of pesticides sold in the market during two years.

\section{Results and Discussion}

Survey results showed that around 20 insecticides were available in market for pest management among them Imidicloprid was the popular sold product during both the years followed by thiamethoxam and Coragen similar results were found by Anitha et al., (2005) where Imidicloprid was found effective in managing white grubs. In 2017-18 six insecticides viz., Fipronil, Cypermethrin, Diafenthiuron, Novaluron, Buprofezin, Spinosad were phased out of Junagadh market and three new insecticide options were available for pest control in groundnut they were profenocyper, phosphomidon, lambdacyhalothrin. This trend helps us to say that most of the chemical sold had systemic action and used as seed treatment chemicals.

Survey results that around 11 herbicides were available in market for weed management among them Targa super was the popular sold product during both years followed by Sodium Aciflurofen + Clodinafoppropargyl, Glyphosate were found by Deivasigamani (2016) where whip super and Targa super applied at 2-4 leaf weed stage recorded the least weed counts of individual species. In 2017-18 four herbicides viz., 2,4-D, Oxyflurofen, Paraquat, Propaquizafop + Imazethapyr were phased out of Junagadh market and one new herbicide Clodinafop + Metasulfuron were available for effective control of weeds in groundnut (Fig. 1-3). 
Int.J.Curr.Microbiol.App.Sci (2018) 7(12): 468-473

Fig.1 Percentage of insecticides sold during Kharif (2016-17 \& 2017-18)

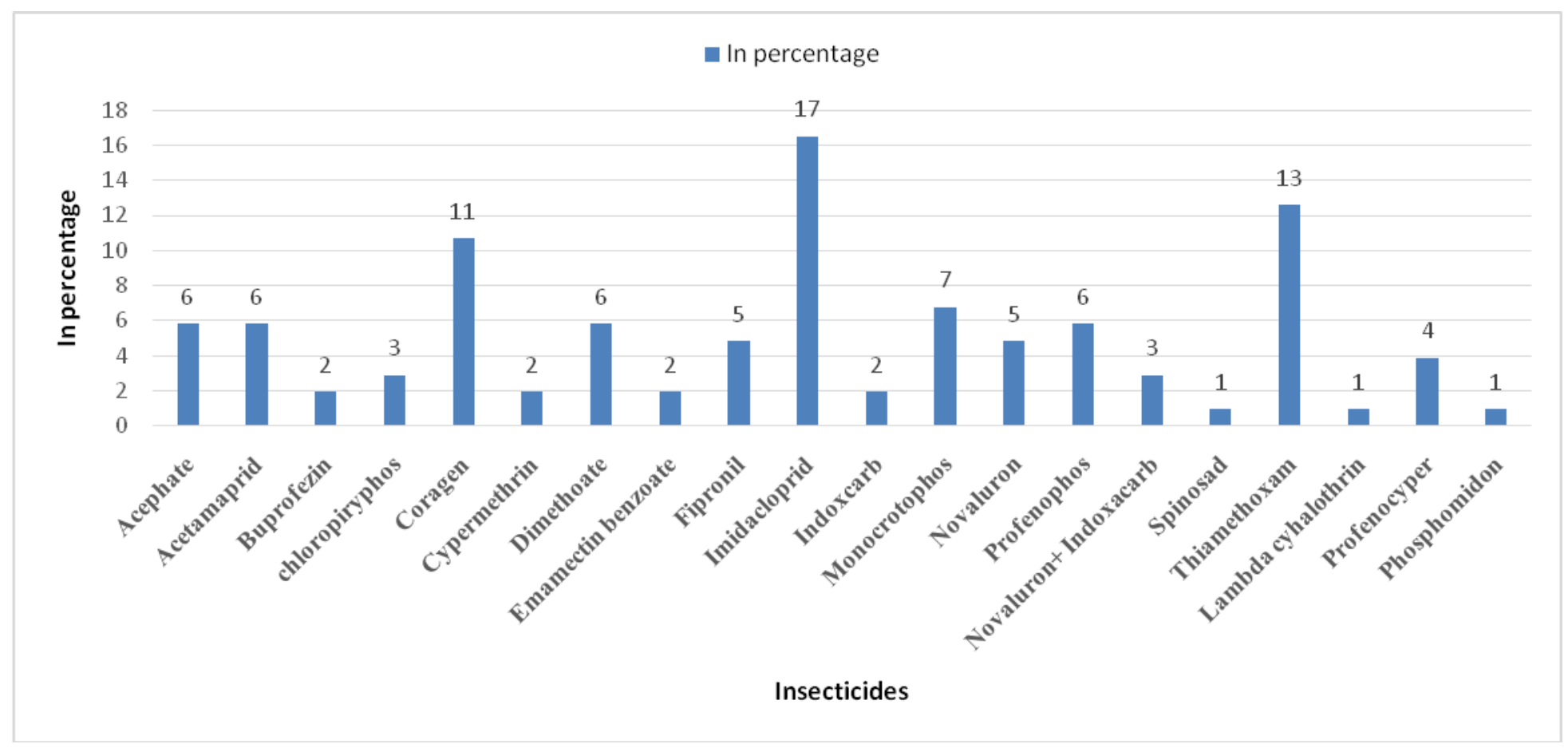


Int.J.Curr.Microbiol.App.Sci (2018) 7(12): 468-473

Fig.2 Percentage of fungicides sold during Kharif (2016-17 \& 2017-18)

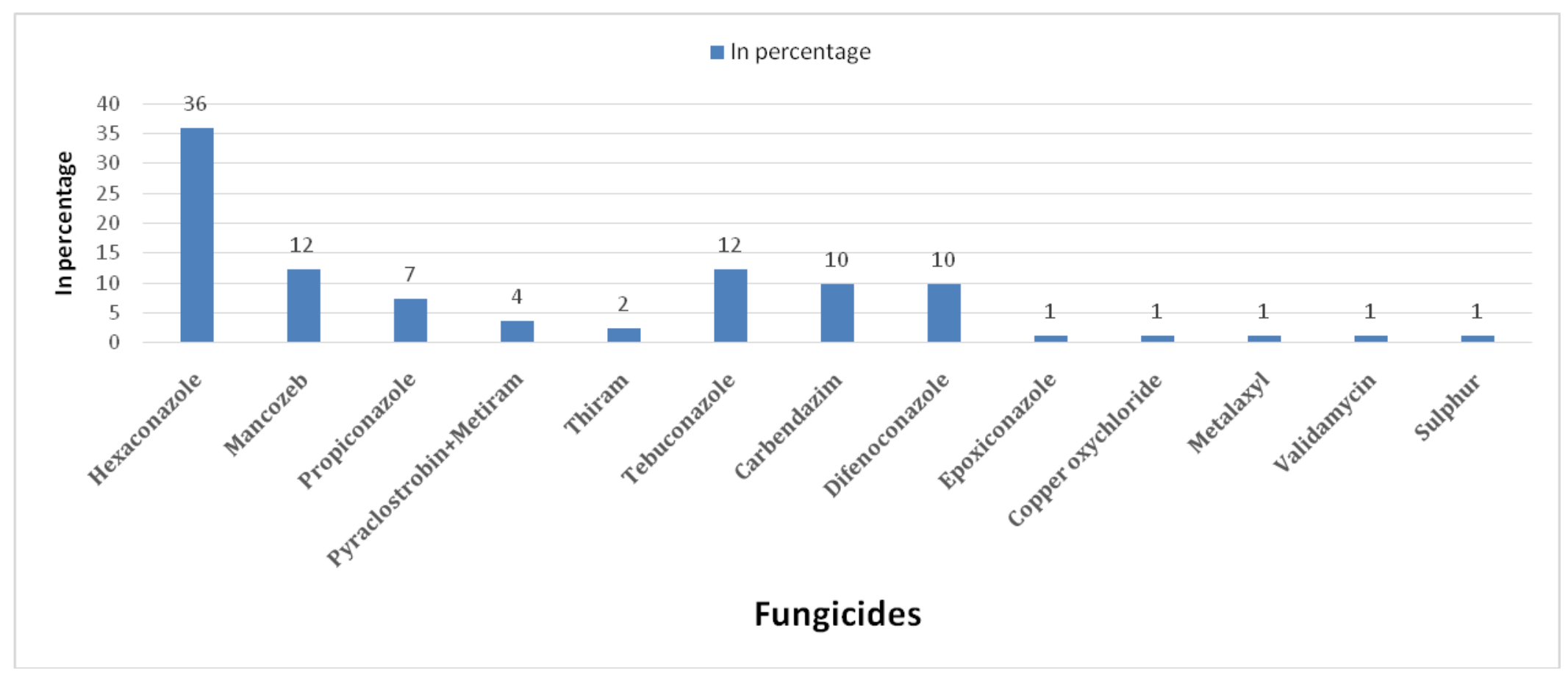


Fig.3 Percentage of herbicides sold during Kharif (2016-17 \& 2017-18)

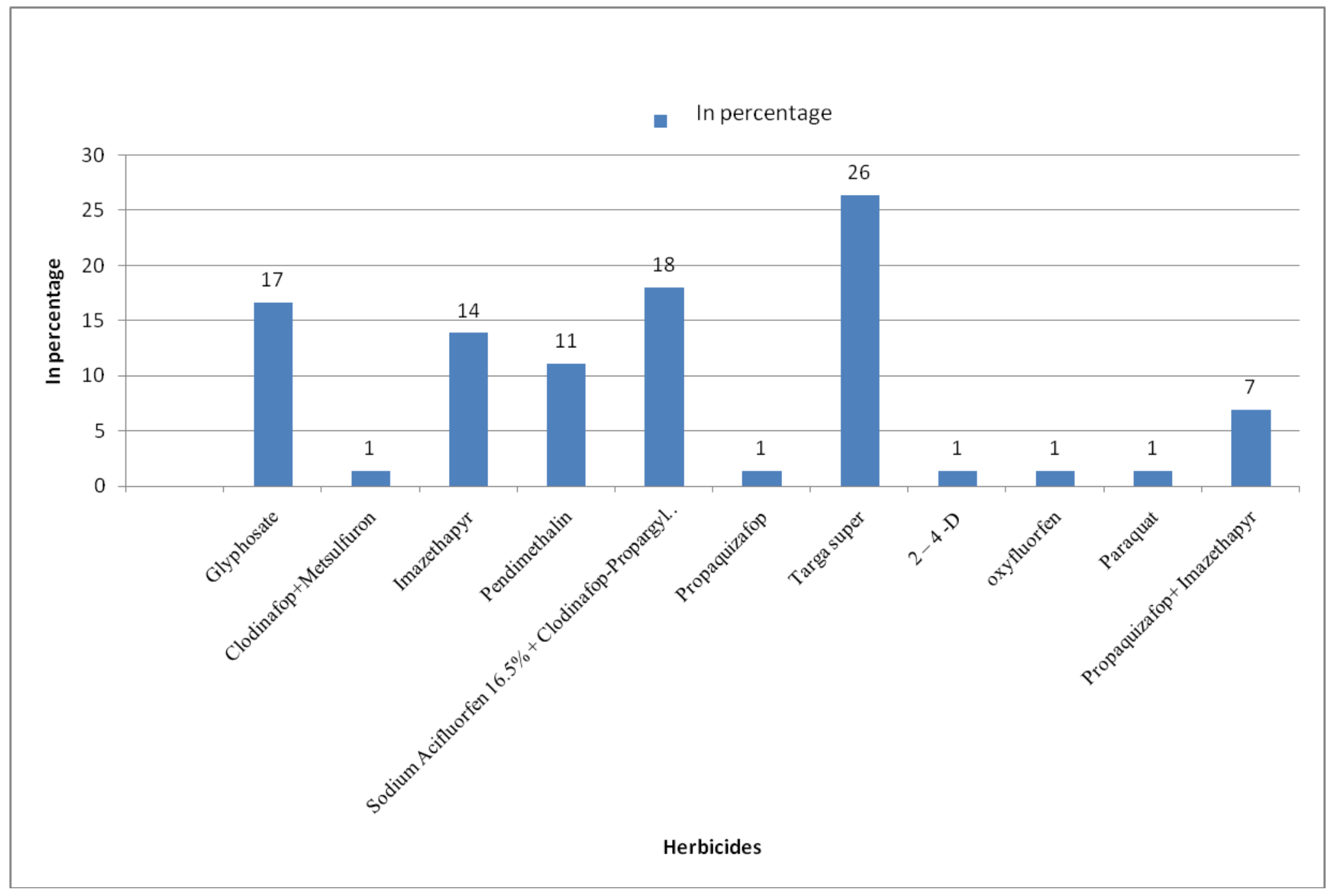


In conclusion, pesticides used in local market follow a dynamic trend based on the incidence of pests and diseases. In case of pests, Recent outbreak of white grubs and lepidopteran pests had resulted in usage of Imidacloprid and Coragen by farmers for management of these pests. In case of diseases, stem rot and Alternaria diseases had resulted more usage of Hexaconazole, thiram, carbendazim for management of the disease. Hence we can conclude that incidence of insect pests and diseases in groundnut has caused such a trend in pesticide market

\section{References}

Anitha, V.; Wightman, J., and Rogers. J. 2005. Management of white grubs (Coleoptera: Scarabaeidae) on groundnut in southern India. International Journal of Pest Management. 51.0.1080/096708705003 99924.

Anonymous. 2016. Directorate of Economics and Statistics, Government of India. www.eands.dacnet.nic.in.

Deivasigamani, S. 2016. Effect of Bio-
Efficacy and phytotoxicity of Fenoxaprop-p-ethyl (Whip super) Groundnut. International Research Journal of Natural and Applied Sciences.3(4): 46-52.

Murthy, B. G.; Agasimani, C. A. and Pratibha, N. C. 1994. Influence of herbicides on yield, quality and economics in rainfed groundnut. Journal of Oil Seeds Research. 11:285287.

Rangarani, A.; Rajan, C. P. D.; Harathi, P. N.; Bhaskar, B. and Sandhya, Y. 2017.Evaluation of Fungicides and Heribicides on Sclerotium rolfsii, Incitant of Stem Rot Diseases in Groundnut (Arachis hypogeal L.). International Journal of Pure and Applied Bioscience. 5(3): 92-97

Sunkad, G.; Mesta, R. K. and Reddy, M. 2005.Field Efficacy of Some Fungicides for Effective and Economical Control Major Foliar Diseases of Groundnut. Journal of Agricultural Science. 18(4): 995-997.

\section{How to cite this article:}

Hithesh, G.R. and Harish, G. 2018. Pesticide Usage Pattern: In Peanut Grown Area of Junagadh. Int.J.Curr.Microbiol.App.Sci. 7(12): 468-473.

doi: https://doi.org/10.20546/ijcmas.2018.712.058 